\title{
A study on communication behaviour of agricultural input users of Udham Singh Nagar district of Uttrakhand, India
}

\author{
Sandeep Rastogi* and Shamsul Hasan \\ Pantnagar (Uttrakhand), INDIA \\ *Corresponding author. E-mail: sanon78@gmail.com \\ Received: February 25, 2014; Revised received: April 20, 2014; Accepted: May 3, 2014
}

Department of Agricultural Communication, Govind Ballabh Pant University of Agriculture and Technology,

\begin{abstract}
This research aims to study the communication behaviour of the agricultural input users or farmers in order to find the deficiencies in this field with expectation to highlight the sources of information preferred and extent of extension agency contacts in the areas. Based on this, a strategy can be worked out to disseminate effective agricultural information to the farmers. The communication behavior in this study includes four variables i.e. mass media exposure, extension contacts, source of information and information satisfaction, covering both overt and covert behavioural components. This study was conducted at Udham Singh Nagar district of Uttrakhand state, where two villages namely; Chhinki and Deoria were selected randomly and from these villages, the data were collected with the help of semi structured interview schedule from randomly selected 160 respondents. The findings revealed that the most preferred (61.25\%) personal localite communication sources for seeking information regarding agricultural practices were their neighbours or family members followed by local agricultural inputs sellers $(13.75 \%)$. From personal cosmopolite sources, $51.87 \%$ respondents were preferred to the representatives of the private companies followed by the agricultural university staffs (40\%). The majority of respondents $(83.75 \%)$ were not associated with any membership in their social system followed by membership (16.25\%). It has been reported that even after the sixty six years of independence farmers are still traditionalists, hardliners, shy and ignorant about the agricultural and overall development of the country.
\end{abstract}

Keywords: Agriculture input, Communication behaviour, Respondents Attitude, Udham Singh Nagar

\section{INTRODUCTION}

Communication is an integral part of development and this is more so in the context of India, where large population still lives in villages and may not be able to take active part in the development process due to illiteracy, shortage of resources, poor infrastructure facilities and low bargaining power etc. (Vittal, 1982). Development refers to, social and economic development, which is possible only through |information, education and communication. The development of farmers depends largely on agricultural development and communication facilitates the benefits of agricultural developments to the farmers. There are many sources through which farmers or agricultural input users seek or get information about the technological changes in farming. New communication technologies, like e-chaupal, information communication technology (ICT) and teleconferencing are engaged in providing information to the farmers. A new approach, popularly known as the agri-clinic and agri-business were adopted by the Government to transfer the new information to modifying the farmers' information seeking behaviour or communication behaviour. It has been also reported that even after the sixty six years of independence, farmers are still traditionalists, hardliners, shy and ignorant about the agricultural and overall development of the country (Diapk et al., 2003).

The communication behaviour refers to the extent to which the farmers are exposed to the different messages from the various communication sources for the sake of adopting messages for proper utilization in their practices. The behaviour of an individual in broad sense refers to, anything the individual does, while in restricted sense, it refers to the activity that can be observed and rewarded. The communication behaviour has been defined with three major components, 1) the receipt of the stimulus 2) the interpretation of the stimulus and 3 ) the response of action. In this study the communication behaviour has been taken as a composite measure of awareness, comprehension, attitude and communication skills, measured by the aggregated score obtained in the components. The communication behaviour in this study includes four variables- mass media exposure, extension contacts, source of information and information satisfaction, covering both overt and covert behavioural components. It is an established fact that communication is the backbone of the development of 
Table 1. Distribution of respondents on the basis of socioeconomic and psychological profile.

\begin{tabular}{|c|c|c|c|}
\hline $\begin{array}{l}\text { S. } \\
\text { N. }\end{array}$ & Characters & $\begin{array}{l}\text { Frequency } \\
(N=160)\end{array}$ & $\%$ \\
\hline \multirow[t]{4}{*}{1.} & Age & & \\
\hline & Young (up to 30 years) & 22 & 13.75 \\
\hline & Middle (31 to 56$)$ & 118 & 73.75 \\
\hline & Old (above 56) & 20 & 12.5 \\
\hline \multirow[t]{5}{*}{2.} & Education & & \\
\hline & Illiterate & 34 & 21.27 \\
\hline & $1^{\text {st }}$ to $5^{\text {th }}$ & 18 & 11.25 \\
\hline & $6^{\text {th }}$ to $9^{\text {th }}$ & 48 & 30.0 \\
\hline & $10^{\text {th }} \&$ above & 60 & 37.50 \\
\hline \multirow[t]{4}{*}{3.} & Caste & & \\
\hline & General & 92 & 57.5 \\
\hline & O.B.C & 64 & 40.0 \\
\hline & $\mathrm{SC} / \mathrm{ST}$ & 4 & 2.5 \\
\hline \multirow[t]{4}{*}{4} & Income & & \\
\hline & Below 80,000 & 28 & 17.5 \\
\hline & 80,000 to $1,20,000$ & 78 & 48.75 \\
\hline & Above $1,20,000$ & 54 & 33.75 \\
\hline \multirow[t]{5}{*}{5.} & Occupation & & \\
\hline & Farming & 94 & 58.75 \\
\hline & Business & 46 & 28.75 \\
\hline & Service & 8 & 5.0 \\
\hline & Labourer & 12 & 7.5 \\
\hline \multirow[t]{3}{*}{6.} & Family type & & \\
\hline & Nuclear & 106 & 66.25 \\
\hline & Joint & 54 & 33.75 \\
\hline \multirow[t]{4}{*}{7.} & Family size & & \\
\hline & Small (up to 4) & 86 & 53.75 \\
\hline & Medium (5-9) & 50 & 31.25 \\
\hline & Large (above 9) & 24 & 15.0 \\
\hline \multirow[t]{4}{*}{8.} & Land Holding & & \\
\hline & Small (up to 4 acre) & 90 & 56.25 \\
\hline & Medium ( 5-10) & 58 & 36.25 \\
\hline & Large (Above 10) & 12 & 7.5 \\
\hline \multirow[t]{5}{*}{9.} & Social Participation & & \\
\hline & No Membership & 134 & 83.75 \\
\hline & Membership in at least & 26 & 16.25 \\
\hline & one organization & 0 & 0.0 \\
\hline & $\begin{array}{l}\text { Membership in more } \\
\text { than one organization }\end{array}$ & & \\
\hline \multirow[t]{4}{*}{10.} & Attitude & & \\
\hline & Low $(15-25)$ & 28 & 17.50 \\
\hline & Medium (25-35) & 98 & 61.25 \\
\hline & High $(35-65)$ & 34 & 21.25 \\
\hline
\end{tabular}

$(\mathrm{N}=$ No. of respondents $)$

the society. Effective communication from different sources and channels are the essence of extension, which provides knowledge and information for rural people to modify their behaviour in the ways that provide sustainable benefits to them and to the society (Gunawardana et.al., 2005). The lack of interest in extension machinery and some social and personal constraints of the farmers make them unable to plasticizing new and improved agricultural practices at
Table 2. Distribution of respondents on the basis of extension agency contacts.

\begin{tabular}{|c|c|c|c|}
\hline $\begin{array}{l}\text { S. } \\
\text { N. }\end{array}$ & Categories & $\begin{array}{c}\text { Frequency } \\
(\mathrm{N}=160)\end{array}$ & $\%$ \\
\hline \multirow[t]{3}{*}{1.} & $\begin{array}{l}\text { Acquaintance with } \\
\text { extension workers }\end{array}$ & & \\
\hline & Yes & 43 & 26.87 \\
\hline & No & 117 & 73.12 \\
\hline \multirow[t]{3}{*}{2.} & $\begin{array}{l}\text { Extension workers con- } \\
\text { tact with respondents }\end{array}$ & & \\
\hline & Yes & 66 & 41.25 \\
\hline & No & 94 & 58.75 \\
\hline \multirow[t]{3}{*}{3.} & $\begin{array}{l}\text { Respondents contact } \\
\text { with extension workers }\end{array}$ & & \\
\hline & Yes & 34 & 21.25 \\
\hline & No & 126 & 78.75 \\
\hline \multirow[t]{4}{*}{4.} & $\begin{array}{l}\text { Purpose of contact with } \\
\text { extension workers }\end{array}$ & & \\
\hline & To obtain financial aid & 40 & 25.00 \\
\hline & To gain free inputs & 108 & 67.50 \\
\hline & $\begin{array}{l}\text { To know agricultural \& } \\
\text { allied information } \\
\text { To gain technical } \\
\text { knowledge }\end{array}$ & $\begin{array}{c}10 \\
2\end{array}$ & $\begin{array}{l}6.25 \\
1.25\end{array}$ \\
\hline \multirow[t]{4}{*}{5.} & $\begin{array}{l}\text { Frequency of contact by } \\
\text { respondents }\end{array}$ & & \\
\hline & Once (in a month) & 28 & 17.5 \\
\hline & Twice (in a month) & 18 & 11.25 \\
\hline & Now and then & 114 & 71.25 \\
\hline \multirow[t]{4}{*}{6.} & $\begin{array}{l}\text { Extension workers } \\
\text { mostly contact with }\end{array}$ & & \\
\hline & Gram pradhan & 87 & 54.37 \\
\hline & Members of Panchayat & 56 & 35.00 \\
\hline & Aam Aadmi & 17 & 10.62 \\
\hline \multirow[t]{3}{*}{7.} & $\begin{array}{l}\text { Most preferred } \\
\text { meeting place }\end{array}$ & & \\
\hline & Neighbours house & 123 & 76.87 \\
\hline & Panchayat ghar & 37 & 23.12 \\
\hline
\end{tabular}

their farm. Thus, keeping in view this study is carried out to find the social, personal and existing constraints which intervene in production potential of the farmers.

\section{MATERIALS AND METHODS}

This study was conducted in Udham Singh Nagar district $\left(28.9800^{\circ} \mathrm{N}, 79.4000^{\circ} \mathrm{E}\right)$, previously known as Rudrapur, of Uttrakhand State. Two villages, namely Chhinki $\left(28^{0} 99^{\prime} \mathrm{N}, 7^{0} 34^{\prime} \mathrm{E}\right.$ ) and Deoria ( $28^{0} 92^{\prime} \mathrm{N}$, $\left.79^{\circ} 48^{\prime} \mathrm{E}\right)$ were selected purposively because of the diversity in agricultural situation, cropping pattern, socio-economic status and infrastructure facilities. The village Chhinki was having an area of 471.85 sq. k.m with population of 2552 , where male and female were 1389, 1163 respectively. While the village Deoria was having an area of 395.39 sq. k.m with population of 1293, where male and female were 540, 753 respectively. Together these two villages have 630 families (374 of Chhinki and 256 of Deoria). From 
these families, 160 respondents were selected randomly by random sampling method. The necessary information was also collected from the secondary information sources like- block of the area, village patwari. Considering the nature of the study, the exploratory research design was used purposively. Independent variables- age, education, caste, family type, family size, occupation, land holding, income, attitude, social participation, extension agency contact and information sources were taken while communication behaviour were taken purposively as the dependent variable. The data from 160 respondents were collected through well structured pre-tested interview schedule. Then the collected data were coded, tabulated, classified and further categorized for systematic statistical analysis using descriptive tools like frequency, percentage, mean, standard deviation, weighted mean score and rank. The outcome of the analyzed data was interpreted accordingly.

\section{RESULTS AND DISCUSSION}

The study regarding socio-economic and psychological characteristics of the respondents presented in the Table 1 revealed that the majority of respondents were from general $(57.5 \%)$ caste followed by other backward class $(40 \%)$ and schedule caste/ schedule tribes $(2.5 \%) .73 .75 \%$ respondents were in the middle age group followed by young $(13.75 \%)$ and old $(12.5 \%)$. Majority of respondents were literate (78.75\%) followed by illeterate $(21.27 \%)$. The income level of respondents depicts that $48.75 \%$ were having medium level of income $(0.8-1.2$ lac.) followed by high $(33.75 \%)$ and low $(17.5 \%)$. In spite of commercialization and industrialization in the areas, the farming (58.75\%) was still major occupation followed by the business $(28.75 \%)$ and labourer $(7.5 \%)$. The majority $(66.25 \%)$ of respondents were having the nuclear family followed by joint family (33.27\%). Most of respondents $(53.75 \%)$ were having small family size followed by medium $(31.25 \%)$ and large $(15 \%)$. The majority $(56.25 \%)$ were possessing small land holding size followed by medium $(36.25 \%)$ and large $(7.5 \%)$. $83.75 \%$ respondents were not associated with any membership in their social system followed by membership with at least one organization $(16.25 \%)$. Only $61.25 \%$ respondents were having medium attitude to use new agricultural technology and inputs at their farm.

Extent of extension agency contacts with respondents: The data regarding extent of extension agency contacts in table 2 indicated that majority respondents $(73.12 \%)$ were having negative response towards the acquaintance with the extension workers in the areas followed by positive response (26.87\%). The extension workers contact with respondents the study shows the majority $(58.75 \%)$ were giving negative opinion followed by positive opinion $(41.25 \%)$. The data regarding respondents contact with extension workers shows, $78.75 \%$ respondents didn't contact with extension workers followed by only $21.25 \%$ were keep in touch. The data regarding purpose of the contact with extension workers shows, the majority $(67.50 \%)$ were contacted to gain free inputs followed by to obtain financial aid $(25 \%)$. The data regarding frequency of contact revealed, $71.25 \%$ respondents were contact (now and then) with the extension workers followed by once in a month $(17.5 \%)$ and twice in a month $(11.25 \%)$. The study regarding extension workers contact with the respondents, the data shows, $89.37 \%$ extension workers used to contact with resource rich farmers followed by aam Aadmi (10.62\%). The majority (76.87 \%) were preferred the neighbours house as their most preferred meeting place followed by Panchayat Ghar (23.12\%).

Source of information used by respondents: In this, under personal localite communication sources for seeking information regarding agricultural practices, $32.50 \%$ of respondents were interacted with their neighbours/friends followed by family members $(28.75 \%)$ and shop keepers $(13.75 \%)$.

In the personal cosmopolite sources, majority of respondents $(51.87 \%)$ were getting interacted with representatives of the private companies followed by agricultural university staff $(40 \%)$. The study regarding mass media availability, the data shows, $48.75 \%$ respondents were having mobile as their mass media communication source followed by television $(23.75 \%)$ and newspaper $(18.12 \%)$. The availability of indigenous source of communication the data revealed, the majority $(38.75 \%)$ was considered religious groups/village meetings as their most frequent used indigenous source of communication followed by local agricultural inputs sellers (24.38\%). The availability of unstructured communication channels for communicate locally were- talk at home/ in the fields/ at the tea stall/ in the village chief's house $(11.87 \%)$ and folk media $(8.75 \%)$.

Information satisfaction: In this, the study was conducted to know the source credibility or trustworthiness of the information source among the respondents. The study revealed that $32.5 \%$ respondents were preferred neighbours/friends as their most credible sources of information regarding the agricultural practices at their farm followed by shop keepers $(28.75 \%)$.

The findings revealed that the penetration of mobile phone is more in the areas than the television sets. This might be due to the period of information technology and reasonable cost of mobile phones. But the television is still most preferred and utilized source for getting information about latest technology related to the agriculture. Also the Doordarshan channel telecasts many useful programmes like Chaupal, Krishi Darshan and Navankur etc. in which much related and useful information about agriculture production technology telecasted for the farmers. The present findings were in 
Table 3. Distribution of respondents on the basis of source of information used by them.

\begin{tabular}{|c|c|c|c|}
\hline $\begin{array}{l}\text { S. } \\
\text { N. }\end{array}$ & Source & $\begin{array}{c}\text { Frequency } \\
(\mathrm{N}=160)\end{array}$ & $\%$ \\
\hline \multirow{8}{*}{1.} & Personal localite & & \\
\hline & Family members & 46 & 28.75 \\
\hline & Neighbours/friends & 52 & 32.50 \\
\hline & Relatives & 8 & 5.0 \\
\hline & Shopkeepers & 22 & 13.75 \\
\hline & Gram pradhan & 8 & 5.0 \\
\hline & Fellow farmers & 16 & 10.0 \\
\hline & Village leaders & 8 & 5.0 \\
\hline \multirow[t]{6}{*}{2.} & Personal cosmopolite & & \\
\hline & B.D.O & 3 & 1.87 \\
\hline & Gram Sewak & 4 & 2.50 \\
\hline & Pvt. Companies & 83 & 51.87 \\
\hline & Agril. university staff & 64 & 40.0 \\
\hline & Teachers & 6 & 3.75 \\
\hline \multirow[t]{9}{*}{3.} & Mass Media exposure & & \\
\hline & Radio & 4 & 2.5 \\
\hline & T.V & 38 & 23.75 \\
\hline & Cable T.V & 3 & 1.87 \\
\hline & Mobile & 78 & 48.75 \\
\hline & Newspaper & 29 & 18.12 \\
\hline & Magazines & 0 & 0 \\
\hline & Campaign & 2 & 1.25 \\
\hline & Panchayat meetings & 6 & 3.75 \\
\hline \multirow[t]{6}{*}{4.} & Indigenous sources & & \\
\hline & Folk media & 14 & 8.75 \\
\hline & Deliberate instruction & 26 & 16.25 \\
\hline & Indigenous organizations & 62 & 38.75 \\
\hline & Service suppliers & 39 & 24.38 \\
\hline & Unstructured channels & 19 & 11.87 \\
\hline
\end{tabular}

accordance with Malik (1991). Dubolia et al. (2002) and Jat et al. (2003). In our social structure, there is a wide gap between intellectuals and local people and this gap going to be broadened (Singh, 2002).

The relevant finding of the study revealed a wide gap between extension workers and farmers in the areas. Extension workers were not contacted by the farmers or vice versa. The majority of the respondents even did not know the name of B.D.O or extension workers of their area.

\section{Conclusion}

The study revealed that the needs and priorities of the farmers have been changed. Many constraints like, lack of knowledge about various recommended cultivation practices, non-availability of basic agricultural inputs on time, high rates of wages, inadequacy of labourer etc., were faced by the
Table 4. Distribution of the respondents on the basis of the information source credibility.

\begin{tabular}{llccc}
\hline $\begin{array}{l}\text { S. } \\
\text { N. }\end{array}$ & Source & $\begin{array}{c}\text { Frequency } \\
(\mathbf{N = 1 6 0 )}\end{array}$ & \% & Rank \\
\hline 1. & Neighbours/ & 52 & 32.50 & I \\
& friends & & & \\
2. & Shopkeepers & 46 & 28.75 & II \\
3. & Family members & 22 & 13.75 & III \\
4. & Fellow farmer & 16 & 10.0 & IV \\
5. & Village leader & 8 & 5.0 & V \\
6. & Gram pradhan & 8 & 5.0 & VI \\
7. & Relatives & 8 & 5.0 & VII \\
\hline
\end{tabular}

respondents. There is an imperative need in the areas that the scattered informations, which are in the form of special bulletins and articles in different journals, magazines, research, reports etc., should be made in the form of a book and circulated to the farmers and extension personnels on reasonable price. Considering the circumstances, it is necessary to make administrative and co-operative machinery more effective and encourage the research and extension system to work on the needs and the priorities of the farmers to bring the prosperity in rural society.

\section{REFERENCES}

Dubolia, S.R., Singh, M. and Sujan, D.K. (2002). Communication behaviour of tribal farmers. PhD thesis at Department of Extension Education, Institute of Agricultural Sciences, Banaras Hindu University, Varanasi, (India).

Diapk, De, Ghadei, K. and Kendadmath (2003). Communication for development in the information age: Extending the benefits of technology for All. In: International Conference, Department of Extension Education, Institute of Agricultural Sciences, Banaras Hindu University, Varanasi, (India), 07-09 January 2003

Gunawardana, A.M.A.P.G. (2005). Communication behaviour of farmers on improved farm practices on Udaipur district of Rajasthan. M.Sc. Thesis, MPUAT, Udaipur.

Jat, S.R., Sharma, V.P., Punjabi, N.K. and Manhas, J.S. (2003). Information input and processing behaviour of opium poppy cultivators. Raj. J. Ext Edu., XI: 50-54.

Malik, W.H. (1991). The role of mass media in diffusion of agricultural technology in Pakistan. J. Rural Dev. and Admi, 23 (3): 62-69.

Singh, V. (2002). Information seeking behaviour of farmers in piprali panchayat samiti of district sikar of Rajasthan. M.Sc. Thesis, RAU, Bikaner, Campus- Jobner.

Vittal, N. (1982). Effectiveness of communication with the rural poor. A study in IRDP district. Journal of Rural Development. 1 (4): 611-659. 